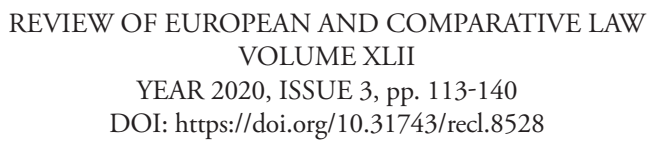

\title{
CAMPUS GOVERNANCE IN U.S. UNIVERSITIES AND COLLEGES
}

\author{
William N. LaForge*
}

\begin{abstract}
This article provides an overview of the main elements and characteristics of campus governance and administration employed by U.S. institutions of higher learning, with a closer look at the practices and operations of one public, regional university.
\end{abstract}

Keywords: universities, shared-governance, campus management

\section{OVERVIEW}

The governance of universities and colleges in the United States basically follows the concept and spirit of democracy embraced by the nation from its birth. The systems and practices in place at most U.S. institutions of higher learning include collaborative, representative, or collective decision-making arrangements known as shared governance. However, these systems and practices are hardly uniform due to the diversity of governance patterns that reflect the unique and different history, needs, and mission of a particular institution. Sometimes they are differentiated from, and contrasted with, corporate, business, and more authoritarian or centralized forms of institutional governance.

* William N. LaForge, President of Delta State University, Mississippi, e-mail: wlaforge@deltastate.edu. 
Campus governance, per se, includes a number of features that generally serve and support the manner in which decisions are made concerning the institution as a whole or one of its constituent components, and how a university is organized, managed, and operated. Those features vary according to the type, needs, and complexity of an institution. But, they typically include common functions such as policy, processes, procedures, legal relationships, general rights and responsibilities, sources of authority, administration and management, organizational structure, decision-making responsibilities, and the relationships, roles, and collaboration among campus administrators and the various university constituencies.

In contrast with university governance elsewhere in the world - that can range from strong central government control to private self-regulated operations - the U.S. forms of campus governance have emerged in a country that does not have centralized authority over education. U.S. institutions of higher learning respond to a variety of controls and interests that are on display variously at public, private non-profit, private for-profit, and religious universities. Governance, authority, and administration are spread across a wide spectrum of players, including governing boards; presidents, chancellors, and other administrators; the academy/faculty; administrative staff; campus committees; students; and, even some external factors.

\section{SHARED GOVERNANCE}

The phrase most often associated with the governance of U.S. universities is shared governance. This concept is widely considered to be a basic tenet of higher education, and it is a key factor in the administration and operation of American universities. However, over time, the meaning of shared governance has morphed to the point where, regardless of its importance and continued application, it is confusing to, or misunderstood by, even those who are engaging its principles. In short, it is an ever-changing and developing concept. As shared governance has evolved over many years in the United States, it has developed increasingly more representation in campus decision-making processes by a wide array of stakeholders. Most contemporary university leaders in the U.S. reportedly tend to char- 
acterize shared governance as "shared responsibility for the welfare of the institution," and as "an equal distribution between [sic] consultation, rules of engagement, and a system of aligning priorities" ${ }^{1}$.

Shared governance has its definitional roots in a well-known 1966 "Statement on Government of Colleges and Universities" that was commissioned and adopted by the American Association of University Professors (AAUP), the American Council on Education (ACE), and the Association of Governing Boards of Universities and Colleges (AGB). The statement is an attempt to lay out common principles of shared governance, and to underscore the importance of the concept $t^{2}$.

Governance is defined in that document as "the joint efforts in the internal operations of institutions," but it also allows for certain decisions to be made within the bailiwick of different groups. While not offered as a template for institutional decision-making, the statement nonetheless proposes that numerous members of the university community should have input on key decisions - the core principle of shared governance including the governing board, president, administrators, and faculty. The thrust of the concept is that, for matters involving general education policy, strategic and long-range planning, budget priorities, and selection of the institutional executive officer, decisions should be joint or shared by a number of constituent groups. Reflecting strongly-held democratic principles, shared governance connotes consultative and participatory roles by various stakeholders on a university campus ${ }^{3}$.

Shared governance has been described as more complex than merely a guide for consensus-building, decision-making, or assigning tasks and responsibilities. It is essentially a balance among various campus players including boards, presidents, faculty, and staff - concerning participation in planning and decision-making processes that ostensibly result in productive actions and administrative accountability. The sharing concept

1 Autumn Arnett, "Finding Shared Governance on Campus", EDUCATIONDIVE (January 26, 2018): 1.September 2, 2019 https://www.educationdive.com/news/finding-shared-governance-on-campus/515635/.

2 "Statement on Government of Colleges and Universities", American Association of University Professors (AAUP) (1966): 1-10. September 4, 2019 https://www.aaup.org/ report/statement-government-colleges-and-universities

3 "AAUP Statement". 
involves delegating to various campus groups a role in key decision-making processes, while also assigning specific decision-making to designated groups - some elected, others appointed, or volunteers ${ }^{4}$.

To be clear, this shared authority does not necessarily mean that every campus constituency will have a participatory role in every decision or at every stage of the decision-making process, and it does not guarantee that any constituency will be able to have control over a process or decision. Quite commonly, advice, consultation, collaboration, and consensus are operative forms of engagement in shared governance. For example, while a search committee to identify and recruit a new faculty member provides a forum for various parties, including faculty and students, who are involved in the process, a chair or dean makes the final decision from a list of recommended candidates. Similarly, student government exists, in part, to make decisions about certain student-oriented activities such as social and cultural events on campus, and the faculty, through a senate or academic council, typically make curriculum decisions ${ }^{5}$.

The sharing aspect of shared governance is broad and encompassing in scope. It tries to balance decision-making participation with defined accountability, and provides a voice for campus constituencies and select groups to engage in campus decision-making. Most observers believe that a major focus on communication with and among all involved parties engaged in shared governance is a basic requirement of successful outcomes ${ }^{6}$.

The scheme of shared governance can be quite complex, and there is no single "one size fits all" organizational approach or methodology. The sharing process typically involves a number of stakeholders or groups with varying degrees of authority and responsibility. Each institution basically adopts its own system and methodology.

4 Gary Olson, "Exactly What is 'Shared Governance?", The Chronicle of Higher Education (July 23, 2009): 2-3. August 19, 2019 https://www.chronicle.com/article/ExactlyWhat-Is-Shared/47065.

5 "AAUP Statement", 4.

6 "AAUP Statement", 5. 


\section{ASSOCIATION OF GOVERNING BOARD'S (AGB) THRESHOLD CONDITIONS FOR EFFECTIBE SHARED GOVERNANCE AND GENERAL PRINCIPLES FOR BOARD GOVERNANCE}

In a 2017 research project titled "Shared Governance: Changing with the Times", the Association of Governing Boards reported some basic conditions that support the design and implementation of effective shared governance in any institution of higher learning, while also reaffirming the need for best practices to be tailor-made to suit a particular university.

1. A shared commitment on the part of faculty, administration, and board members to the principles of shared governance and a current, shared understanding among faculty, board, and president of what shared governance actually is and how it operates/functions/ works in their institution.

2. A shared and clearly articulated commitment to trust, collaboration, communication, transparency, inclusiveness, honesty, and integrity.

3. An institutional culture of good will, good intentions, and commitment to common values that is reinforced through the practice of shared governance. Clear policies concerning authority and standard operating protocol are important to develop, but without goodwill and commitment to shared values, they can't lead to effective decision making on meaningful issues.

4. A shared commitment among all parties to focus the practice of shared governance on the institution's strategic goals, aspirations, and challenges.

5. Constitutional documents (such as bylaws, faculty handbooks, policy statements) that clearly codify decision-making authority as well as a thorough, nuanced understanding on the part of board members, faculty, and presidents of their own respective roles in shared governance, as well as those of their colleagues.

6. A shared appreciation by board members and faculty of the complexity of the president's role in facilitating a constructive relationship between the board and the faculty.

7. A recognition that while students, staff, and contingent faculty often do not have a formal role in shared governance, boards, presidents, and faculty should create regular opportunities to in- 
clude their voices in the discussion of important issues and major decisions.

8. A shared recognition that institutional change is necessary, constant, and inevitable; the dynamically changing external environment and continued institutional relevance demand it. All stakeholders must be open to doing things differently when circumstances require.

9. A recognition that the most important decisions are often the most difficult and contentious, but that the preservation of relationships is vital to sustained effectiveness in governance.

10. A recognition by the president, board chair, and faculty leadership that they have collective responsibility to ensure that the above conditions exist"

The ABG study observed that, "The most relevant question about shared governance facing governing boards, presidents, and faculty is: How can the principles of shared governance best be applied in the context of circumstances that are more complex and dynamic than they were even a generation ago? The practice of shared governance is, in many institutions and in various ways, changing with the times. It is important for practitioners to assess local policies and procedures as they exist today to determine - often collaboratively, sometimes creatively - the most promising ways forward given the challenges ahead. Board members, presidents, and faculty alike would do well to examine the threshold conditions above in determining where shared governance needs additional work in their institutions"8.

The AGB study concluded that "shared governance is an essential component of America's higher education institutions that needs to be preserved and enhanced". It recommended that, "The notion that shared governance practices should be continuously reviewed for potential improvement hints at a key finding of this study: shared governance is a dynamic system that can become ineffective. The purpose of such assessments

7 "Shared Governance: Changing with the Times", An Association of Governing Boards of Universities and Colleges (AGB) White Paper (March 29, 2017): 12. September 5 , 2019 https://agb.org/reports-and-statements/shared-governance-changing-with-the-times/

8 "AGB Shared Governance". 
should be to ensure that, in both policy and practice, shared governance supports the institution's strategy and vision"'.

\section{THE PLAYERS/STAKEHOLDERS IN SHARED GOVERNANCE}

In the scheme of shared governance, a wide array of stakeholders can play a role in decision-making at various levels of authority and in certain circumstances, depending on their campus position and relationship to an issue or decision. Each university has its own discreet set of "players". However, there are several stakeholders who are typical participants in any shared governance structure.

\subsection{Governing Board}

The U.S. higher education governance model begins with a governing board, in which legal governing authority is vested, and from which that authority is exercised. For public universities, created constitutionally or by statute, governing boards are usually appointed by the governor or other public authority, and operate under the auspices of state laws and regulations, typically with oversight by, and budget accountability to, the state legislature. These governing boards are variously established with authority over a statewide system of public universities or over just one institution. For private and religious institutions, respectively, charter documents and individual religious denominations establish the institution, dictate how board members are selected, and hold the institutions accountable under budget and administrative policies.

Board members, holding the title of governors, trustees, regents, directors, overseers, visitors, or something similar, typically serve for a term of years established by law or policy. Governing boards establish basic institutional policy, engage in strategic planning, set standards and expectations, create and/or approve budgets, and hire an institutional executive officer

9 "AGB Shared Governance", 11. 
(IEO), whom they hold accountable for performance, programming, and the general administration of the operations of the institution ${ }^{10}$.

While the authority of governing boards varies from campus to campus, most boards essentially act as the "holder of the trust" of the university's mission, and serve as custodians and overseers of the institution's assets, funds, and general operations. They are ultimately responsible for the institutions they serve, and they stand guard over the sacrosanct notion of academic freedom. Board members can come from a wide variety of professional backgrounds, and often include university alumni, elected officials, community and business leaders, and civic-minded individuals. Board membership and service are considered an expression and practice of civic duty in the United States, and service is typically voluntary in the spirit of citizen governance - a concept that is part of the fabric of the American form of democracy ${ }^{11}$.

In its 2010 "Statement on Board Responsibility for Institutional Governance", the Association of Governing Boards of Universities and Colleges (AGB) outlined general operational principles and responsibilities for institutional boards:

1. The ultimate responsibility for governance of the institution (or system) rests in its governing board.

2. The board should establish effective ways to govern while respecting the culture of decision making in the academy.

3. The board should approve a budget and establish guidelines for resource allocation using a process that reflects strategic priorities.

4. Boards should ensure open communication with campus constituencies.

5. The governing board should manifest a commitment to accountability and transparency and should exemplify the behavior it expects of other participants in the governance process.

6. Governing boards have the ultimate responsibility to appoint and assess the performance of the president.

10 "Governance and Decision-Making in Colleges and Universities", Education Encyclopedia - State University.com (2019): 2. September 5, 2019 https://education.stateuniversity.com/pages/2014/Governance-Decision-making-in-Colleges-Universities.html.

11 "Governance and Decision-Making", 2-3. 
7. System governing boards should clarify the authority and responsibilities of the system head, campus heads, and any institutional quasi-governing or advisory boards.

8. Boards of both public and independent colleges and universities should play an important role in relating their institutions to the communities they serve"12.

The governing board's formal delegation of authority to an institutional executive officer (IEO) to manage the day-to-day operations of the institution begins and further enables the sharing of authority with respect to campus governance.

\subsection{Institutional Executive Officer (IEO) - President/Chancellor}

Higher institution boards delegate authority and responsibility for the administration of institutional operations to an executive officer (IEO), commonly called a president or chancellor, whose role, function, and responsibilities are similar to those of a chief executive officer (CEO) of a corporate business. As the chief campus administrative officer, the IEO leads and manages the institution, implements and administers policies set by the board, guides the university according to established policies and procedures, and hires and leads other key administrators. The IEO oversees university programming, establishes long-term strategic goals, as well as short-term operational goals, and, together with his/her leadership team, basically oversees all the operations of the campus, ranging from academic, student, and financial affairs, to athletics, fundraising, alumni relations, and external/community relations. Shared governance occurs as the IEO engages campus constituencies in decision-making, delegates authority and management over certain aspects of the university to other officials on campus, and holds those individuals accountable for executing policy and programs, as well as for achieving results.

12 "Statement on Board Responsibility for Institutional Governance", Association of Governing Boards of Universities and Colleges (AGB) (January 22, 2010): 5-9. September 5, 2019 https://agb.org/wp-content/uploads/2019/01/statement_2010_institutional_governance.pdf 


\subsection{Key Administrators}

Principle administrators serving under the IEO may include a wide array of vice presidents, academic deans, department chairs, program directors, managers, and other professionals who have responsibility for a particular aspect of the university's programs or activities. Typically, the head of the academy is a vice president, provost, or a similarly titled official who has top-down administrative responsibility for all academic, faculty, curriculum, and teaching functions. Vice presidents for finance, student affairs, research, advancement, external affairs, executive affairs, university relations, and other key areas are also frequently employed at U.S. universities. Their respective portfolios and responsibilities vary from campus to campus. All of these administrators share in the governance, management, and administration of the university with regard to the personnel, programs, and functions under their respective purview.

\subsection{President's Cabinet or Council}

Most universities operate with a president's cabinet or council that, in one form or another, includes officials who represent all or most of the key constituencies and functions on campus. This forum of representatives of the university serves as a major platform for campus governance, policy-setting, decision-making, budget prioritization, and advisement for the president and other officials. They engage variously in long-range planning and in short-term operational decisions. Some members of the cabinet may serve continuously as long as they hold a certain position, such as a vice president with a particular portfolio. Other cabinet members may change individually from time to time as their constituent groups change leadership. In most cabinet organizational models, the highest form of shared governance can be found in practice. In true democratic style, cabinet members represent a campus sector, administrative portfolio, or other constituent group. Yet, they work collaboratively to discuss issues, make decisions, arrive at consensus, and help shape the direction and mission of the university. Periodic meetings are typical, complete with an agenda, minutes, business action items, discussion topics, and a general sharing of the campus's activities and environment among colleagues, both in general 
and on specific topics. The record of Cabinet deliberations and decisions is generally made available to the university community, if not to the general public, as well.

\subsection{President's Executive Committee/Council (EC)}

Some universities employ the use of a small, select, top-level executive committee or council to consider major issues on campus, serve as a "steering committee" or sub-cabinet group for decision-making and policy implementation, and support the president as close advisors. This group can meet regularly or at the call of the president, and it typically includes the vice presidents and any other top officials of the university preferred by the president. This executive committee or council assists the president with advice and decisions on major issues, including those that are driven by a sense of urgency. It can also serve as a planning group for issues that need full cabinet attention. The EC usually consists of the president's closest and top advisors, such as the vice presidents, and, thus, serves as another forum for the practice of shared governance.

\subsection{The Faculty and the Faculty Senate}

The faculty of a university are the essence of the academic institution, and they play an important historical role in the governance of universities in the United States. The imperative for their engagement stems simply from the fact that the faculty are the heart and soul - the core - of the university in their instructional, research, and service capacities. They typically have a role in a wide spectrum of matters and processes ranging from policies, decisions on the curriculum, rank and tenure, and subject matter and methods of instruction, to research agendas, faculty status, consideration of the university budget, and the safeguarding of academic freedom on campus. They set the requirements for general education courses and for the degrees granted by the university, and authorize the university to grant degrees. Members of the faculty engage in these areas of review and decision-making at all levels in campus processes, from the inner workings of their departments, divisions, colleges, and schools, to service on numerous important campus-wide and departmental committees, to the evalua- 
tion of student progress, and up the administrative ladder to the academic council and the university president's cabinet. The faculty provide valuable support to the administration through their interaction, advice, and recommendations on issues such as salaries, course loads, and department chair selection.

In addition to the traditional institutional involvement afforded the faculty as described above, most U.S. university faculty exercise much of their shared governance role through a faculty senate. The university faculty senate is a longstanding tradition at U.S. institutions of higher learning. Comprising elected members from across the academy, the faculty senate can be a small (15-30) or large (a hundred or more) representative group in size, depending on the size, organization, and needs of a particular university. It is one of the basic and most important forums and outlets for the faculty's engagement in shared governance on a campus.

Faculty senates meet regularly, and, depending on the institution, can be charged with responsibilities for many of the functions outlined above. Additionally, faculty senates often fulfill the role of providing "checks and balances" to the university administration, another democratic principle borrowed from the U.S. governmental model. They have been known to evaluate administrators and programs on campuses, offer opinions and advice on any number of issues, and even censure or express lack of confidence in the performance of a president or other university official. The scope of issues that the faculty senate may consider is basically endless, including organizational, structural, social, cultural, work-place, and academic matters. Its basic mission is to represent the best interests of, and speak for, members of the academy. Its discussions, recommendations, and actions are intended to advise the administration and influence university-wide decision-making. Many universities include the faculty senate president as a member of the university president's cabinet, further enhancing the practice of constituent representation and shared governance.

\subsection{Academic Council}

Many universities utilize an academic council to focus on concerns and decisions that specifically affect the academy, curriculum, academic calen- 
dar, class schedules, and related matters. This council is usually chaired by the vice president for academic affairs or provost, and its membership normally includes academic deans, the registrar, and other key officials with direct responsibility for academic decision-making. The academic council is a vital component of many universities' organizational structure, and it is charged with significant decision-making authority. In this way, the academic council is a major player in the realm of shared governance and authority. Some universities also include a representative from the academic council on the university president's cabinet as another way to practice shared governance.

\subsection{Academic Colleges and Schools}

For administrative purposes, most universities divide the academy into organizational units known as colleges or schools, typically presided over by a dean. These entities consist of various academic departments, divisions, and programs. Colleges and schools within a university structure are empowered to engage in substantial decision-making regarding the departments, divisions, and programs within their purview, and the dean works with the chairs and other faculty members to consider issues and make decisions pertinent to their academic fields. Additionally, some institutions utilize a deans' council to advise and work with the academic vice president or provost on certain matters and decisions affecting the colleges or schools. These collaborations are further examples of shared governance.

\subsection{Academic Departments, Divisions, and Programs}

Similar to the above description of shared authority and decision-making opportunities and practice for an institution's colleges and schools, the next organizational level down - academic programs, divisions, and programs - also engages in significant ways with respect to academic programs, curriculum, majors and minors, teaching assignments, and course content, as well as the overall mission of the entity. Departments and divisions are typically led by a chair, and programs usually have directors or managers. 


\subsection{Administrative Staff Council}

Just as the faculty organize a representative senate, members of the university administrative staff often organize a staff council. This council typically is an association of non-faculty and non-administrative employees of the university, and its leadership is elected or selected from the staff population. Much of the council's activity generally surrounds professional development, workplace improvement, and matters and activities relating to its membership. However, the staff council frequently has a voice and a role in discussing and considering decisions regarding campus affairs that are specific to the administrative staff, and even to the university at large. The council often makes recommendations for consideration by the president's cabinet, and many universities include the chair or president of the administrative staff council as a full voting member of the president's cabinet. As an engaged constituency, the administrative staff council and its membership participate in the exercise of shared governance.

\subsection{Campus Committees and Task Forces}

On most university campuses, a considerable amount of work, research, programming, and planning is conducted through a variety of university committees and task forces. Most institutions have standing committees that devote attention to institutional matters such as tenure and promotion, and certain aspects of campus engagement, activities, and life. Sometimes a special committee or a task force might be appointed to address a specific topic, such as a search, a particularly difficult topic, complaints, a campus process such as the appeal of a personnel decision, or any number of concerns. Committees and task forces are typically populated by either a cross section of campus stakeholders, or a group of individuals from a specific area with expertise in that field. In at least a minimal way, the functions of campus committees and task forces also serve the purpose and mission of shared authority and governance. 


\subsection{Alumni Relations/Affairs}

While not directly involved with the main thrust of a university's mission - i.e. instruction, research, and student development - the alumni affairs function on a campus plays an important role in keeping graduates of the institution connected to their alma mater and knowledgeable about campus affairs, even if from afar. A university director of alumni relations/ affairs and his/her staff are the liaisons between the university and alumni, and those relationships are valuable to the institution from a perspective of support (financial, volunteer, and program), reputation, pride, and other forms of engagement, such as recommending students for admission and sponsoring alumni-based social events. To some extent, alumni association boards, chapters, and even individuals are given the opportunity to provide input on general university matters, at least in the form of opinions or advice to the university administration. In most cases, they also self-govern with respect to the organization, structure, and activities of the alumni association itself. Shared authority is not highly prevalent in the context of alumni relations, but it does exist to some degree, especially in the form of a voice from an important constituency of the institution.

\subsection{University Foundation/Fundraising and Donors}

All U.S. institutions of higher learning engage in fundraising from a wide variety of sources, including alumni, government grants, businesses, private foundations, and friends of the university. This enterprise is typically conducted by university officials, per se, in the case of private universities in some cases, or, in the case of public universities, by a separate, private foundation established for the sole purpose of raising private funds for the university in support of its mission. In the case of private foundations, a separate board of directors or trustees essentially governs the foundation and its activities, usually in conjunction with the university's advancement functions.

Foundation board members can be drawn from the ranks of alumni, local businesses, political leaders, university friends, and donors. These individuals are usually high profile, successful professionals who volunteer to serve the foundation as a civic and educational duty. While 
usually preoccupied with the major challenge of raising funds for the university, these individuals carry a high level of credibility and respect in university circles, and their opinions and advice matter to the university leadership. Donors to a university, especially major gift donors, also may engage in a more direct way with the university in ways such as directing the use of funds given for student scholarships, research, or any number of university functions that may be designated to receive financial support from the donor. In these ways, however tangential or minimal, foundation boards and financial donors join in the exercise of shared governance on many campuses.

\subsection{Student Engagement}

The involvement of students and their voice in the administration of a university is an important feature in higher education. After all, students are the raison d'etre for the institution's very existence. They are our target audience and the primary users of our services. Student engagement can take many forms, including student government activity, student service on university committees, and the voice of student organizations across a wide spectrum of interests, ranging from honorary, service, and fraternal societies to religious, professional, and sporting clubs. Student government is quite prevalent throughout the U.S. higher education world. Through self-governance relating to student-focused issues on campus, student leaders are elected and appointed to various positions to represent and serve their student peers in conducting a wide array of student-related functions on campus. This service provides the benefit of a democratic leadership laboratory for those students who participate.

The student voice on a college campus is important and should be heard. Most universities embrace methods to involve students formally in issue discussion, information dissemination, and, to some extent, decision-making regarding policies that affect students and their academic and extracurricular activities. For example, campus committees dealing with searches, policy consideration, and activities often include student members. Some universities even include the president of the student 
body as a non-voting or even full-voting member of the university president's cabinet.

There is a long-standing tradition of student voice and expression on U.S. university campuses that underscores and celebrates both the American legacy and constitutionally protected right of free speech, and the university's role in providing a forum for expression, discussion, and debate for any of its constituents, especially its students. University administrations are wise to listen to student interests, and engage the student voice. Student opinions and actions can and do influence university administrative decisions on many levels. In all these cases of student engagement individually and collectively - a certain, if modest, element of shared governance is afforded to students.

\subsection{Intercollegiate Athletic Department/Activities}

A large majority of U.S. universities sponsor intercollegiate athletic activities in a number of sports. Athletics is a major part of university life in America, and it can be both a big business and a big budget item for an institution. The responsibility for these enterprises falls to the university athletic department, typically headed by an athletic director. That individual hires the team coaches and oversees all the sports programs and their budgets. While ancillary to the academic mission of a university, college sports are embedded in the fabric of higher education in the U.S. like nowhere else in the world. College athletics are important to sports fans, alumni, donors, recruiters, and the universities at large. Those individuals and corporate sponsors who support college athletics, as well as fans and alumni, feel a vested interest in their chosen university sports programs. University pride, reputation, and standing are often influenced greatly by the success and effectiveness of the athletic program. Consequently, as a major constituent of a university's domain, the athletic department has a certain modicum of input in university decision-making related to budgets and priorities. Thus, to some extent, shared authority and governance extend to intercollegiate athletic programs, as well. 


\section{OTHER INFLUENCERS, OVERSEERS AND ENGAGEMENTS}

While not directly involved with campus governance, per se, numerous external factors, regulatory entities, and organizational engagements and activities often influence a U.S. university's attitude toward, and practice of, shared authority and governance.

\subsection{Institutional and Program Accreditation and Certification}

Absent a central governmental authority overseeing U.S. higher education, as is found in many countries around the world, U.S. institutions of higher learning, nevertheless, must undergo the scrutiny and approval of U.S. Department of Education-endorsed accreditation agencies that are organized by region around the country. These entities employ higher education experts and evaluators whose job it is to visit, audit, evaluate, and accredit colleges and universities in America to ensure high standards of academic and business performance. That accreditation is the gold standard for U.S. universities, and compliance is always an issue, both during periodic evaluations and continuously throughout the years between evaluations.

These accreditors set the standards for a variety of university functions, including faculty credentials, curriculum design, campus governance, budget processes, and other activities central to a university's success. In addition to institutional accreditation at-large, certain academic colleges, schools, departments, and programs in the U.S. are also subjected to required or recommended specific accreditation by a recognized national or regional evaluation entity in a particular field or concentration. Similarly, there are certification programs for various academic disciplines and their faculty. In these vital, if extended, ways, external accrediting and certifying entities have a role in - and certainly an important influence on - the notion of campus shared governance.

\subsection{Governmental Involvement and Oversight}

All U.S. universities are subject to a variety of governmental influence and oversight that can emanate from federal, state, and local governmental 
agencies and regulation. At the top of the list for public universities, of course, is their governing board, which is constituted by their respective state government. State universities also depend, at least to some extent, on budget support from their state, so the state budget process and legislative oversight apply to public universities and colleges. State regulatory agencies also have a hand in overseeing university enterprises, such as state-sponsored retirement programs, environmental compliance, and building and renovation supervision. Examples of federal government involvement and oversight also include federal regulation of student tuition grant and loan programs, mandated federal civil rights and social programs, federal research and service contracts, and compliance with a plethora of federal laws and regulations concerning taxation, health and safety, environmental concerns, and immigration policy, among many others. Local governments may have special relationships with a university regarding public services and land usage. Governmental relationships at all levels play an important role in how a university governs and administers its operations and programs.

\subsection{Professional Associations}

U.S. universities, their academic units, and individual faculty members often belong to national, regional, and state professional membership associations that provide a variety of services, resources, and targeted engagement opportunities for their membership. There are several national associations that serve and support higher education generally, as well as specific organizations for discreet sectors such as public, private, or religious institutions. These organizations typically concern themselves with academic and leadership conferences, research, standards, best practices, educational trends, and issue management, as well as publications, information dissemination, and government relations services.

There are also national associations in specific academic fields that serve the departments and faculty members in those areas of endeavor. These associations provide important and unique resources and capabilities for universities and their stakeholders, and, thus, can play a significant role in supporting professional development, research and other scholarly endeavors, increased institutional and individual knowledge 
and skills, and networking with other professionals in the higher education world.

Through these relationships and avenues, professional associations can have an influence on how an institution governs and manages itself.

\subsection{Unions}

Many universities in the U.S. engage with one or more trade unions on their campuses. These unions represent sectors of a university's employment base, and, consequently, have an influence on employment conditions and compensation. Some observers argue that unions today are actually a part of shared governance on campus because of their importance and influence in university decision-making.

\subsection{Relevant Legal Precedents and American Jurisprudence}

U.S. universities are subject to federal and state constitutional, code, and case law jurisdiction. Federal and state laws, and court decisions in the U.S. common law system, all play an important role in shaping the organization and actions of institutions of higher learning.

Basic U.S. constitutional concepts, such as due process and equal protection, permeate the organization and processes of U.S. universities. The First Amendment of the United States Constitution that provides individual guarantees of freedom of speech and assembly, coupled with a long line of case law precedents, ensure that these special liberties and protections remain intact everywhere in the country, including on college campuses.

The totality of federal and state codified laws that affect higher education can be considered part of the framework in which institutions of higher learning have to operate. As examples, the federal Family Education Rights and Privacy Act (FERPA) affords students certain rights of privacy relating to their student records, and The Health Insurance Portability and Accountability Act (HIPAA) provides data privacy and security measures for safeguarding medical information.

More specifically to higher education, there are numerous lines of court decisions dealing with tenure, promotion, academic freedom, free speech, research outcomes, intellectual property, and myriad other topics. 
Like society in general, universities must be attentive and subject to the laws of the land, and jurisprudential influences on higher education are extensive.

\subsection{Community Engagement/Town-Gown Relations}

U.S. universities strive to foster good relations with the city, town, or locale in which they are situated. There is considerable and mutual benefit to cooperation and collaboration on matters ranging from events and activities to facility use and project sponsorship. The basic fabric of good town-gown relationships typically includes some modicum of economic, cultural, and social interdependence. Universities also embrace various forms of community engagement that can include providing programs, classes, and facilities for local citizens; organizing conferences; supplying faculty and student volunteers for charitable projects; and, hosting visitors for special educational, cultural, and social events. These relationships and collaborations that focus on positive community engagement have an important influence on the operations and roles of a university.

\subsection{Media Influence}

Like all organizations and sectors in the public eye, universities are subject to the scrutiny and influence of the media. Whether a university is being proactive in placing advertisements, providing stories for print or broadcast, or responding to press inquiries and investigations, the influence of the media is always present. University communication and marketing plans and activities help shape the image, brand, and reputation of the institution. And, the media's influence - including social media more than ever - can have a significant impact on the public relations and publicity strategies of a university, as well as on internal operations.

\subsection{Other Engagements, Arrangements, and Examples}

There are countless examples of other activities, engagements, and arrangements - far too many to list here - that foster and support shared authority and governance on a university campus. These examples usually 
entail internal operations such as faculty and staff personnel searches, program reviews, selection of departmental chairs, and special projects that serve the university or one of its departments or programs. Typically, representatives from the faculty and staff ranks undertake these responsibilities, thus contributing to shared decision-making and governance.

\section{SHARED GOVERNANCE THROUGH THE LENS OF ONE INSTITUTION - DELTA STATE UNIVERSITY}

I can perhaps comment most authoritatively about the informal model and system of shared governance employed at the university that I lead Delta State University in Cleveland, Mississippi.

Delta State is a rather typical public, regional state university in the southern region of the United States with an enrollment just under 4,000 students. Our academic offerings are organized and delivered through a nursing school, a graduate school, and three colleges - Arts and Sciences, Business and Aviation, and Education and Human Sciences.

As president, I consider shared governance to be a key element in how Delta State is governed and managed. From an organizational and structural perspective, the university employs many of the functions and features outlined above, and discussed in more detail below. In numerous ways, the key tenets of shared governance permeate campus administrative, management, and decision-making processes at all levels.

However, a vital part of shared governance is the attitude with which it is approached and implemented. By that, I mean the need for genuine sharing of ideas, superb communication, active participation, transparency, and trust on the part of all players or stakeholders. It means giving voice to campus-wide interests in a truly deliberative manner. It includes hearing all sides of an issue before making a decision, and ensuring that voices and votes matter. While no system is ever perfect, I believe that Delta State enjoys a high level of shared governance, because its leaders and its stakeholders are committed to the principle. Like democracy, shared governance is often difficult and challenging because it requires the investment of a significant amount of time and energy - by many stakeholders - in communicating, consulting, researching, collaborating, and, ultimately, decision-making. 


\subsection{Shared Governance Practices and Engagement at Delta State University}

The profile and practice of shared governance at Delta State University include many of the elements and features previously discussed. The sharing aspect begins with a system-wide governing board that hires the IEO. The Board of Trustees of the Institutions of Higher Learning of Mississippi, appointed by the governor for nine-year staggered terms, and its Commissioner of Higher Education, appointed by the Board, delegate the administration and management of this university to me as president. In turn, I lead the university, and engage the campus constituencies, in a variety of ways to ensure representation of viewpoints in discussions and deliberations that lead to decisions, and I delegate a significant amount of decision-making to other administrators and groups.

The president's cabinet is a very important ingredient in this engagement. My cabinet consists of ten professionals representing basically every area of activity on campus: Vice President for Academic Affairs and Provost; Vice President for Executive Affairs and Chief of Staff; Vice President for Finance and Administration/Chief Financial Officer; Vice President for Student Affairs; Vice President for University Advancement and External Relations; the Director of Athletics; a dean representing the Academic Council; the president of the faculty senate; the chair of the administrative staff council; and, the president of the student government association. The cabinet meets weekly throughout the year, and is the basic representative decision-making body on campus with respect to policy, programming, and budgeting. The cabinet also meets for one or two days each summer in retreat fashion to consider long-range and strategic planning, and to address major issues or challenges confronting the institution.

The president's executive committee consists of the five vice-presidents noted above. We meet weekly, as well, to consider key campus issues prior to cabinet review, and to formulate decisions on any number of matters that need to be made in a timely fashion. The five vice-presidents are my closest advisors on campus, and, together, we comprise the top leadership and administrative team for the university.

The university academic council advises, and is chaired by, the Vice President for Academic Affairs and Provost. It considers academic pro- 
grams and issues, the curriculum, degree requirements, and the academic calendar. It is composed of the deans of the university, - including Arts and Sciences, Graduate School, Education and Human Sciences, Business and Aviation, Nursing, and Library Sciences - Registrar, president of the faculty senate, executive director of the Student Success Center, and chief information officer. It can make recommendations to the president's cabinet, but it also shares some independent decision-making with the Provost.

The Provost also presides over periodic meetings of the informal Deans Council that is charged with overseeing the general administrative and academic guidelines used to govern the respective schools and colleges, and implementing strategies. Within each college or school, a dean provides leadership, and works with the departmental and divisional chairs to conduct and administer the business of the academy. Chairs routinely meet with members of their respective department or division to ensure implementation of the academic mission, and to address issues and details specific to that particular unit. Academic decision-making is distributed and shared throughout these processes.

As a matter of institutionalized policy, Delta State University recognizes representative bodies that foster and practice shared governance. These entities include the faculty senate, administrative staff council, and committees, all of which participate in university policy discussions and decisions, as discussed below ${ }^{13}$.

The faculty at Delta State University fulfill most of the basic roles, and are afforded the respect and engagement, outlined in the general section above on "The Faculty and Faculty Senate". The faculty senate at Delta State serves as the pinnacle delivery system for the faculty voice. It is an active and very representative organization with delegates from every quarter of the academy. Senators are elected from their respective academic units, with a total senate composition of twenty-four, plus a proxy for each senator, when needed. At any given time, four dozen members of the faculty can be engaged in senate activities. The senate meets monthly to discuss a wide array of issues and concerns, and to formulate recommendations to

13 Delta State University Policies, "Representative Bodies," (2019) September 9. 2019 http://www.deltastate.edu/policies/policy/university-policies/university-governance/representative-bodies/ 
the administration. The senate president sits on the university president's cabinet, thus providing representation of the faculty in the highest decision-making forum on campus ${ }^{14}$.

Similarly, the university's administrative staff council enjoys representation on the university president's cabinet, thus affording all campus staff a voice and vote on major decisions. University staff from all quarters of campus select representatives from their respective administrative unit to serve on a council of thirty members. The council's elected leadership guides programming that focuses on professional development, workplace issues, and service. ${ }^{15}$

Dozens of campus standing and special committees, variously composed of faculty, staff, and students, engage in a number of important functions involving review and decisions concerning campus policies, hiring, adjudications and appeals, tenure and promotion, and internal operations. These engagements further support the university's effort to involve important constituencies in campus governance.

The president of the student government association also serves on the university president's cabinet, with full representational and voting rights. This arrangement ensures a direct link from the student body to the highest decision-making on campus. Delta State recognizes and respects the educational and participatory value and benefits of student engagement in campus issues and decision-making as important features of a thriving university, and we encourage our students to be involved on many levels.

Intercollegiate athletics is an important component of Delta State's mission, alongside the primary focus on academics. These competitive programs afford our student-athletes the opportunity to continue playing their chosen sport at a very high level during their college years. The director of athletics serves on the university president's cabinet, and brings a representational voice and vote to that body from this important sector.

14 "Delta State University Faculty Senate", (2019) September 5, 2019 http://www. deltastate.edu/about-dsu/administration/faculty-senate/

15 "Delta State University Administrative Staff Council Constitution and By-Laws", (2019) September 5, 2019 http://www.deltastate.edu/MediaFiles/Administrative-Staff-Council-Bylaws-Updated-Sept-2016.pdf 
The functions and activities of alumni relations and development/ fundraising fall under the jurisdiction of the Vice President for University Advancement and External Relations, who has a seat on the president's cabinet. The boards of both the Alumni Association and the Foundation, composed mostly of Delta State alumni and supporters, provide valuable support, contacts, and networks for the university, and their voices and interests regarding issues of concerns are heard and considered by the university.

Delta State University and our faculty and staff have a healthy level of engagement with national, regional, and state professional associations that help support the professionalism of our enterprises. The university also works cooperatively with federal and state governmental and regulatory entities to comply with a variety of education-based and work place laws and policies. The university itself is accredited by the Southern Association of Universities and Schools Commission on Colleges, and many of our academic programs, such as nursing, art, counselor education, business, aviation, accounting, social work, teacher education, and music, are accredited or certified by their respective accrediting bodies. And, we engage with our local communities in a wide array of ways, with an eye toward maintaining excellent town-gown relations. A recent study showed that the university has a $\$ 175$ million economic impact on our surrounding region.

All of these engagements, relationships, and practices serve to support the concept of shared governance at Delta State, and they are all important to our operations, success, and future.

\section{CONCLUSION}

As a concept, shared governance is not new to me. As student government president of this university a half century ago, I championed and spoke about shared authority and governance on a university campus. I also embraced the practice during my tenure as national president of the Delta State University Alumni Association more than three decades ago. Today, I have the opportunity to put it into practice as president of my university. 
Shared governance is not a perfect formula or panacea for university administration and decision-making. It does, however, provide a methodology, system, and concept that can help guide the leadership of a university as it approaches the administration and conduct of its educational responsibilities. In today's higher education environment, the term governance is rather expansive. In one sense, it means top-down governance that is the rightful role and authority of an institutional board charged with overseeing policy, programming, performance, and executive guidance and evaluation. But, it also variously means the use of institutional strategies, operations, and components to distribute, disseminate, and "share" authority and responsibilities for a university's administrative, management, and decision-making functions, i.e., "on-campus governance". In this respect, shared governance "borrows" many of the attributes and principles of democratic government. In any case, shared governance, in its many forms and applications, is widely practiced in U.S. universities, including Delta State University.

Shared governance supports and advises university leadership and management in important ways. Its practice institutionalizes the welcoming of information and perspectives that can help lead to better information and decisions, and more sustainable decision-making processes. As the campus IEO at Delta State, I rely on the advice, perspectives, and experience of my colleagues in most, if not all, major decisions made on this campus. Their guidance and engagement help the university - and me - make decisions that are reasoned, responsible, fair, and appropriate, while taking into consideration the individual and collective stakeholder interests involved. Together, we attempt to make decisions and take actions that are ultimately in the best interest of the university and our students.

The practice of shared governance, I believe, results in better, well-considered decisions and policies that enjoy the support of a broad array of university stakeholders due to their participation in the processes of deliberation and decision-making. To be successful, its application requires significant time, engagement, thought, and communication, but the return on the investment can be high and rewarding. 


\section{REFERENCES}

Arnett, Autumn A. January 26, 2018. "Finding Shared Governance on Campus" EDUCATIONDIVE. September 2, 2019 https://www.educationdive.com/ news/finding-shared-governance-on-campus/515635/.

"Delta State University Administrative Staff Council Constitution and By-Laws". 2019 September 5, 2019 http://www.deltastate.edu/MediaFiles/Administrative-Staff-Council-Bylaws-Updated-Sept-2016.pdf.

"Delta State University Faculty Senate”. 2019. September 5, 2019 http://www. deltastate.edu/about-dsu/administration/faculty-senate/.

Delta State University Policies, "Representative Bodies”. 2019. September 9. 2019 http://www.deltastate.edu/policies/policy/university-policies/university-governance/representative-bodies/.

"Governance and Decision-Making in Colleges and Universities". Education Encyclopedia - State University.com (2019): 2. September 5, 2019 https://education.stateuniversity.com/pages/2014/Governance-Decision-making-in-Colleges-Universities.html.

Hollinger, David A. No date. "Faculty Governance, The University of California, and the Future". AAUP's FOOTNOTES. August 19, 2019 http://depts. washington.edu/uwaaup/shared.htm.

Olson, Gary. "Exactly What is 'Shared Governance?". The Chronicle of Higher Education: 2-3. August 19, 2019 https://www.chronicle.com/article/ExactlyWhat-Is-Shared/47065.

"Shared Governance: Changing with the Times". March 29, 2017. An Association of Governing Boards of Universities and Colleges (AGB) White Paper: 12. September 5, 2019 https://agb.org/reports-and-statements/shared-governance-changing-with-the-times/.

"Statement on Government of Colleges and Universities". 1966. American Association of University Professors (AAUP): 1-10. September 4, 2019 https:// www.aaup.org/report/statement-government-colleges-and-universities.

"Statement on Board Responsibility for Institutional Governance". January 22, 2010. Association of Governing Boards of Universities and Colleges (AGB): 5-9. September 5, 2019 https://agb.org/wp-content/uploads/2019/01/ statement_2010_institutional_governance.pdf. 